scores in RA patients treated with TCZ. PGA was the major limiting factor for not achieving ACR/EULAR Boolean remission criteria, and in this sub-group of patients the same positive correlation between higher PGA and fatigue scores was found, not present in the rest of the cohort. These results enhance the influence of fatigue in patients' perspectives of disease and reinforce the limitations of using $P G A$ to define RA activity and remission. Furthermore, considering the influence of TCZ in fatigue mechanisms, by blocking IL-6 receptor, we still found high fatigue scores in this cohort, which can enhance the complex physiopathology of fatigue in chronic inflammatory diseases, and the role of several other cytokines (IL-1, TNF- $\alpha$ ). This effect and comparison with RA patients treated with anti-TNF- $\alpha$ can be explored further in larger prospective studies.

Disclosure of Interest: None declared

DOI: 10.1136/annrheumdis-2017-eular.2502

\section{AB0239 DKK1 IS NOT ASSOCIATED WITH INFLAMMATORY ACTIVITY INDEXES IN RHEUMATOID ARTHRITIS, BUT WITH FUNCTIONAL DISABILITY RELATED TO THE LONG EVOLUTION OF THE DISEASE}

R. Giraldo-Bustos ${ }^{1}$, E.L. Saldarriaga ${ }^{1}$, A.M. Santos ${ }^{1}$, J.I. Angarita ${ }^{1}$, J.G. Ballesteros ${ }^{1}$, J.C. Rueda-Sanchez ${ }^{1}$, A. Vasquez ${ }^{1}$, L. Valero ${ }^{1}$, S. Arias ${ }^{2}$ J. Londono ${ }^{1}$ on behalf of Grupo de Espondiloartropatías Universidad de La Sabana - Hospital Militar Central. ${ }^{1}$ Department of Rheumatology; ${ }^{2}$ Universidad de la Sabana - Hospital Militar Central., Bogotá, Colombia

Background: Rheumatoid arthritis (RA) is a systemic chronic inflammatory disease characterized by joint destruction, deformity, lower functional status and decrease in life expectancy. Wnt signaling pathway recently it has been implicated in bone homeostasis. Studies suggest that overexpression of inhibitors of the way, like the Dickkopf 1 protein (DKK1) has been implicated in bone destruction

Objectives: To compare circulating levels of DKK1 in patients with RA to their disease activity and functional status

Methods: 379 consecutive patients with early and established RA were evaluated at the Hospital Militar Central in Bogota-Colombia, between March 2015 and November 2016. A complete medical history related to RA was obtained. Disease activity was evaluated by DAS28-CRP, CDAI, SDAI and RAPID3. functional status was measurement using MDHAQ and the Steinbrocker functional classification. DKK1 levels measured by ELISA using an Abcam ${ }^{\circledR}$ kit

Results: The mean age was $60,7 \pm 13,1$ years, disease duration $13,1 \pm 10,9$ years, $80,4 \%$ were female. Higher levels of DKK1 were not associated with higher disease activity by CDAl $(p=0,70)$, SDAI $(p=0,84)$, DAS28 with CRP $(p=0,80)$ or RAPID3 $(p=0,70)$. Interestingly Higher levels of DKK1 were significantly associated to greater disability and lower functional status according to the Steinbrocker functional grading $(p=0.013)$ and with severe disability by MDHAQ $(p=0.004)$, Table 1 .

Other variables associated with joint destruction were osteoporosis, elevated rheumatoid factor, smoking, and hospitalization

\begin{tabular}{|c|c|c|c|}
\hline $\begin{array}{l}\text { Steinbrocker functional } \\
\text { grading }\end{array}$ & $n(\%)$ & $\begin{array}{c}\text { DKK1 (pg/mL) } \\
\text { M } \pm \text { ds }\end{array}$ & $P$ \\
\hline Class I-II & $286(75,2)$ & $4930,9 \pm 8061,5$ & \multirow[t]{2}{*}{0,013} \\
\hline Class III-IV & $93(24,5)$ & $7930,6 \pm 10811,3$ & \\
\hline MDHAQ & & & \\
\hline Without or low disability & $334(88,0)$ & $3192,0 \pm 2729,4$ & \multirow[b]{2}{*}{0,004} \\
\hline $\begin{array}{l}\text { Moderate or severe } \\
\text { disability }\end{array}$ & $45(12,0)$ & $4445,67 \pm 2821,0$ & \\
\hline
\end{tabular}

Conclusions: Higher levels of DKK1 were found in patients with lower functional status. This association was not found in patients with greater disease activity according to CDAI, SDAI, DAS28 and RAPID3. This could be explaining by greater structural damage though more studies would be needed to explore this possibility

References:

[1] Huizinga TW, Pincus T. In the Clinic. Rheumatoid arthritis. Ann Intern Med. 2010 Jul 6;153(1):ITC1-1-ITC-15.

Disclosure of Interest: None declared

DOI: 10.1136/annrheumdis-2017-eular.1518

\section{AB0240 ASSOCIATION BETWEEN LEPTIN CONCENTRATIONS AND CARDIOVASCULAR RISK IN PATIENTS WITH RHEUMATOID ARTHRITIS}

J.A.D.J. Batún Garrido ${ }^{1}$, I.E. Juárez Rojop ${ }^{2}$, M. Salas Magaña ${ }^{2}$, É. Hernández Núñez ${ }^{1}$, F. Olán ${ }^{1} .{ }^{1}$ Hospital Regional de Alta Especialidad Dr. Gustavo A. Rovirosa Pérez; ${ }^{2}$ Universidad Juárez Autónoma de Tabasco, Villahermosa, Mexico

Background: It has been observed that leptin plays a role in the development of cardiovascular risk, independently associated with the development of atherosclerosis, as well as with traditional risk factors such as obesity and arterial hypertension, on the other hand, its participation in carbohydrate and lipid metabolism and in coagulation, makes leptin a promoter of the complications of obesity and therefore increase cardiovascular risk.
Objectives: Identify whether there is a relationship between serum leptin concentrations and cardiovascular risk assessed using the Framingham scale. Methods: We studied patients with the diagnosis of rheumatoid arthritis (RA) according to the ACR/EULAR 2010 criteria; the leptin determination was through an enzyme immunoassay (ELISA) with the TECO ${ }^{\circledR}$ Test Kit. Cardiovascular risk was calculated using the modified Framingham score, as reported by EULAR, the result obtained was multiplied by 1.5 . Were considered as risk values of $<1 \%$ as low; $1-5 \%$ moderate and $>5 \%$ high. Statistical analysis was performed using the SPSS 22.0 package. A $p \leq 0.05$ was considered a significant result. Categorical variables were compared with $\mathrm{Chi}$ square test. Continuous variables were compared with either the Student's T test or the Mann-Whitney non-parametric test, according the case.

Results: We studied 77 patients. The traditional CVR factors that presented the highest prevalence were age, hypoalphalipoproteinemia and obesity; With regard to the prevalence of non-traditional factors, hyperleptinemia, glucocorticoid use and positive RF were predominant. More than $3 / 4$ parts of the study population consumed methotrexate and hydroxychloroquine, which have been considered as CVR protective factors. Serum leptin concentrations and CVR factors were compared and found that there was a significant difference between higher leptin values and disease activity $(p=0.047)$, obesity $(p=0.038)$, positive rheumatoid factor $(\mathrm{p}=0.009)$, Tobacco $(0.009)$ and metabolic syndrome $(\mathrm{p}=0.001)$. Likewise, a significant relationship was found between lower leptin concentrations and hydroxychloroquine consumption ( $p=0.023$ ). Framingahm CVR was calculated and the result obtained was multiplied by 1.5 . The $35.2 \%$ of the population studied had a low Framingahm RCV, 38.9\% moderate and $25.9 \%$ presented a high risk. We compared the level of CVR and serum leptin concentrations, finding that the highest CVR were the leptin values.

Conclusions: There is a positive association between CVR and serum leptin concentrations. It is also significantly associated with traditional and non-traditional risk factors

References:

[1] Raggi P. Epicardial Adipose Tissue as a Marker of Coronary Artery Disease Risk. J Am Coll Cardiol. 2013; 61(13): 1396-139.

[2] Correia M, Haynes W. Leptin, obesity and cardiovascular disease. Curr Opin Nephrol Hypertens. 2004; 13 (2): 215-23.

Disclosure of Interest: None declared

DOI: 10.1136/annrheumdis-2017-eular.6968

\section{AB0241 RELATIONSHIP BETWEEN LEPTIN AND DISEASE ACTIVITY IN PATIENTS WITH RHEUMATOID ARTHRITIS}

J.A.D.J. Batún Garrido ${ }^{1}$, I.E. Juárez Rojop ${ }^{2}$, M. Salas Magaña ${ }^{2}$, É. Hernández Núñez ${ }^{3}$, F. Olán ${ }^{3}{ }^{1}$ Medicina Interna, Hospital Regional de Alta Especialidad Dr. Gustavo A. Rovirosa Pérez; ${ }^{2}$ Universidad Juárez Autónoma de Tabasco; ${ }^{3}$ Hospital Regional de Alta Especialidad Dr. Gustavo A. Rovirosa Pérez, Villahermosa, Mexico

Background: Increased concentrations of leptin have been observed during infectious processes and inflammation, in such a way that it plays a role in the inflammatory and the immune response

Objectives: Determine the association between serum leptin and disease activity measured through DAS-28 PCR.

Methods: Patients with the diagnosis of rheumatoid arthritis (RA) according to the ACR/EULAR 2010 criteria were studied. Leptin was determined by enzyme immunoassay (ELISA) with the TECO ${ }^{\circledR}$ Test Kit, the values higher than $17 \mathrm{ng} / \mathrm{mL}$ were considered as hyperleptinemia. Disease activity was assessed by the DAS-28 PCR, classifying as remission $<2.3$, low activity $\geq 2.3$ to $<3.8$, moderate activity as $>3.8$ to $<4.9$ and high activity $>4.9$. Statistical analysis was performed using the SPSS 22.0 package. A $p \leq 0.05$ was considered a significant result. A multivariate logistic regression model was used to determine the association between significant variables and leptin concentrations.

Results: 77 patients were studied, $93,5 \%$ were female. The activity of the disease was determined, finding that $40,3 \%$ of patients were in remission, $41,6 \%$ had low activity, $11,7 \%$ had moderate activity and $6,5 \%$ had high activity. The $46,8 \%$ had obesity, $32,5 \%$ were overweight, $18,2 \%$ had normal weight and $2,5 \%$ were underweight. The $37,7 \%$ of the patients studied had metabolic syndrome, being the main factor the presence of an altered abdominal perimeter. The $63,6 \%$ had positive rheumatoid factor. The $71,4 \%$ had leptin levels $\geq 17 \mathrm{ng} / \mathrm{ml}$. A multivariate logistic regression was performed with leptin as dependent variable. The results show an independent association between higher concentrations of leptin and disease activity (OR 1,$9 ; 95 \% \mathrm{Cl} 1,3-3,8 ; p=0,045$ ), obesity (OR 3,63; $95 \%$ $\mathrm{Cl} 1,1-11,9 ; p=0,033)$, the presence of metabolic syndrome (OR 2,74;95\% Cl $1,7-10,4 ; p=0,038$ ), and positive rheumatoid factor (OR 3,$5 ; 95 \%$ IC 1,2-11,3; $p=0,033)$. It was also found that at higher disease activity, there were higher concentrations of serum leptin. Patients with severe activity had higher leptin media than patients in remission

Conclusions: There is a positive relationship between the activity of the disease and the serum leptin concentration, likewise this hormone is related to other inflammatory processes such as metabolic syndrome and rheumatoid factor.

\section{References:}

[1] Tilg H, Moschen A. Adipocytokines: Mediators linking adipose tissue, inflammation and immunity. Nat Rev Immunol. 2006; 6: 772-83.

[2] Otero M, Lago R, Lago F, Casanueva F, Dieguez C, Gómez J. Leptin, from 